\title{
COGNITIVE MEANINGS OF MANAGEMENT CONTROL IN ESTIMATING THE DEGREE FOR ACHIEVING THE STRATEGY
}

\author{
Alina Puțan ${ }^{1}$ \\ Dan Ioan Topor ${ }^{2}$ \\ Maria Gheorghian ${ }^{3}$
}

ABSTRACT: The control shall provide to managers the information dynamic, real, preventive, which raises the value of conclusions and quality decisions. Control is a tool for knowing reality, and the possibility of identifying and preventing deficiencies and anomalies. Control penetrate the essence of the phenomenon, support managers in efficiently management, allows the notification of negative aspects when they manifest as a tendency, and comes operatively for preventing and removing the causes that led to their.

For the strategy to be implemented includes: preset order, a change of already existing procedures, an involvement of all participants in the effective exercise of the entity and the regulatory and control instruments.

Keywords: management control, strategy, decision.

JEL Codes: M41.

\section{Introduction}

Management accounting and management control are becoming increasingly components of modern management and developed today in a coherent set of methods, techniques, processes and efficient tools, the wildcard character, but customizable, from careful study and comprehensive of all sectors of activity.

Through a review of the literature, we will first define what we understand with management control and strategy. We will show the evolution of these two different fields. On the one side, management control goes off accounting to take managerial aspects into account. The important thing is not the tool of control itself but how it is used by managers (Simons 1994, 1995).

As regards strategy, the "strategy as a practice" research field proposes to study the strategy, not as an abstract concept or an economic phenomenon but as the result of everyday actions and interactions.

Because of the contemporary contexts that are we a series of questions appears: management control is just a tool to check? To surveillance? Or is much more and becomes an instrument in pilotage entity? What indicators are the bases for the decisions? For whom? Why?

Management control and strategy assume a really complex process. Their implementation is closely related objectives of the entity. Control objectives are interdependent with the proposed strategy. Are managed resources needed and training of personnel of control and improvement of methods and control procedures, how to assess the controls etc.

\footnotetext{
1 "1 Decembrie 1918" University of Alba Iulia, Romania, e-mail: putan.alina@yahoo.com

2 "1 Decembrie 1918" University of Alba Iulia, Romania, e-mail: dan.topor@yahoo.com

3 "Valahia" University Targoviste, Romania, e-mail: mariagheorghian@yahoo.com
} 


\section{Research literature}

In our own study we have done appeal to methods of research as documentation, comparison, analysis, synthesis, to achieve proposed objectives. The documentary was a method used with preponderance. We have used the work of Professor Briciu Sorin, Nadia Albu, James Don Edwards, Tabără Neculai, etc.., articles, publications. In the last part of our work we tried to present a series of conclusions drawn from our analysis regarding subject study method. The research method used was the synthesis.

By using a rich bibliography, we were able to identify issues relevant for current practice, aspects of relationship management-decision-control strategy. The importance of this relationship derives from the role it has in the effective and efficient management of the entity.

\section{The evolution of management control in time and space}

R.N. Anthony (2007) defines management control as the process by which managers ensure that resources are obtained and used efficiently and effectively in achieving the objectives of the entity. Also, emphasizing the role of management control in decision making, the same author claims: "the controls are the process of guiding of a set of variables to reaches a predetermined goal or target".

R.Garrison and E.Noreen (2000) suggests another definition of management control as these measures to taken to increase the probability that management objectives are attained and to ensure that all parts of the organization works according with the policies of the entity.

In framework of some paper that are situated in the area of management control, are given new dimensions of management control: economic and strategic dimensions, but also organizational and psychosocial (M.P.Follett,1924; R.N.Anthony, 1956, 1965, 1988; R.L.Simons, 1987; H.Savall, 2003; H.Savall and V.Zardet, 2004; L.Cappelletti and D.Khouatra, 2007; H.Savall, V.Zardet, Bonnet and L.Cappelletti, 2006; R.Chenhall and K.J. Euske,2007). Through the control shall be provided therefore efficient and effective use of the resources the aim of achieving the objectives set.

The concept of "resources" was presumed to be used for evidence of managerial dimension of management control, which is reduced to a simple accounting and financial dimension. (H.Bouquin, 2008).

A more practical perspective, aimed at increasing competition threatened entities, of rapid changes on the market, new forms of organization of the entity and customer orientation is given by R.L.Simons (1995, p. 29): control implies the management of inherent tension between creative innovation on of the one part, and achieving the objectives predicted, on the other hand, so that both turn into profitable growth.

Control of an organization is defined as "a process before actions oriented, during the development of action adjusted and once the action performed, evaluate his results to draw useful lessons" (Boisselier, 1999).

"Management control looking to conceive and develop information tools designed to allow leaders to act, making the global economic coherence between objectives, means and achievements. It should be considered as a useful information system for pilotage company, because it controls the effectiveness and efficiency actions and the means to achieve objectives "(Grenier, cited by Boisselier, 1999).

According to J. Stoner and C. Wanke (1986, p. 17, cited by Anthony, R. and Govindarajan, V., 2007) process of control includes: defining intended results, establishment expected outcomes, setting standards for predictions and results, establishing of information and feed-back, evaluating information and taking decisions. Therefore, this control process implies a list of steps towards specific objectives and whether who these objectives are achieved. 
R.N.Anthony (1988, p. 10, cited d by Chenhall, R., 2003) defines control as "the process through that managers influence other members of the entity to implement this strategy". Also R.N.Anthony, defines planning strategy as means to formulate strategy. In this regard, the literature reveals us that the being the main tool control management, others require planning, organization, personnel coordination.

Management control is considered privileged instrument of management of the whole activities to an economic entity. Visions of contemporary management show transition from the idea of "control-check" the idea of "control and management".

It is impossible to manage without control. Control measure results of management and compares them with targets with the aim of determine whether there is agreement or difference.

From the perspective of management control in international literature, the control means that managers take measures which shall ensure that decisions are made which provide that employees do what is best for the entity (R. Anthony and V. Govindarajan, 2007).

D.T. Otley (1994) believes that control has as main function to ensure appropriate behavior of personnel across the entity.

International literature suggested some significant causes of the need of control, such as absence of management, motivational issues and limitations of staff. In case of control problems, managers can avoid such situations by using strategies that the eliminate, automation and risk classification. (Anthony, RN, 1988, Carroll, JJ, 1987, Chenhall, RH, 2003, Garrison, RH and Noreen, EW, 2000, Otley, DT, 1989).

By studying the literature conclude that management control is at the intersection of three axes fundamental orientation of the actions and behaviors of participants in all work for the objectives of entity relationship, modeling of results with resources and the correlation the strategy to reality.

\section{Decisions and organizational strategy}

Absence of an adequate control may have adverse consequences for the entity. Problems as defective products, unsatisfied customers, discontent employees, inability to compete successfully in the market, organizational discordance at different levels are results of poorly control results, with disabilities.

Otherwise, an override may cause negative moves within the entity, by affecting the efficiency and effectiveness of the activity. On the one part talk about demanding control that can reduce flexibility and innovation. On the other part talk of increasing operational costs and the tension over employees.

A decision implies a satisfactory solution and adequate information.

Finality of management control is to provide information of managers for making decisions about current and long term management of the entity. However obtaining quality decision and performance depend on quality of information provided by management control. Therefore, to be useful to the decision making process, management control information provided must meet the following characteristics: to be feasible, that is to give the best possible representation of reality; to be actual, that is timely; to be complete, that is all the elements that indicate to the decision, however feature complete information aimed at sorting process and ordering information, so they are useful the decision making process; to be relevant, that is to be adapted to the problem concerned; to be accessible to decision makers.

The elsewhere, management control is seen as part of the implementation of the strategy. The motivation is that the without control, proper execution of the strategy is impossible.

Bouquin H. (2008) insists on the fundamental role of management control which allows the management ensures coherence between daily needs and long term defined strategy.

As plan strategy "deals with how leaders try to establish direction for organizations", as ploy, it "takes us into the realm of direct competition, where threats and feints and various other 
maneuvers are employed to gain advantage", as pattern, the strategy "focuses on actions", as position, strategy "encourages us to look at organizations in their competitive environment and as perspective strategy "raises intriguing questions about intention and behavior in a collective context" (Mintzberg, 1987).

Mintzberg $(1987,1989)$ shows that leaders are constantly busy with very fragmented tasks, with little time to devote to the development of the strategy.

Their main task is then to make sense, to ensure consistency of actions that sometimes diverge. He then considers that the realized strategy is the result of a combination of formulation of leaders and daily actions of organizational members.

Such a view opens new perspectives for management control. Its role is then not limited to the implementation of strategy but also to the formulation of strategy, of intended strategies but also on emergent strategies. The formulation of the strategy focuses on the development and selection of specific action plans. Implementation (implementation) includes communication, interpretation, adoption and appropriation plans (Mintzberg and Waters 1985, Noble 1999).

Strategy can be assist several instruments that the budgets, plans and simulations, resulting, therefore the lead role which they hold within the entity budgets.

Strategy is situated on the "quicksand" because his environment of action is unstable and uncertain. Only the production of goods and services does not ensure his existence and the common entity or walking for long periods of time. There is a need innovation at all levels, an innovation in the production hall, but also in mentality.

A strategic approach is a process characterized by uncertainty. The strategy adopted may prove to be of inadequate existing market conditions, leading to loss. Resulting from this increased attention to over the selection of the strategy but also means to adapt.

The interdependence of strategy goes beyond control and the allocation of resources.

Interaction that exists between management control and strategy thanks to the role held by the strategy in an organization and with the place of management control in the strategic process interest to every good manager.

Goold and Campbell three distinct styles of management in diversified companies that they studied in Britain (Bouquin H., 2008):

o "style strategic planning", practiced by companies that are limited to 2 or 3 areas growing strong: the head is powerful, valued conformity and the model meets it quite clearly;

o "style financial control" is found in highly diversified companies engaged in rather mature in stable competitive environments that can be managed by financial indicators in the short term. The branch responsible for developing the strategy, and the seat, encouraging entrepreneurial style, provides a counterweight to a strong finance function ensuring strict monitoring of results;

o "style strategic control" is practiced by companies seeking to build a balanced portfolio spread risk. The organization allows for a grouping of entities by type of strategic mission. The strategy is primarily the concern of these groups, the summit has control detailed according to their mission.

Analysis of time and control strategy level of interaction can be seen in models below, the efficiency theories (Solle G., 2011): 


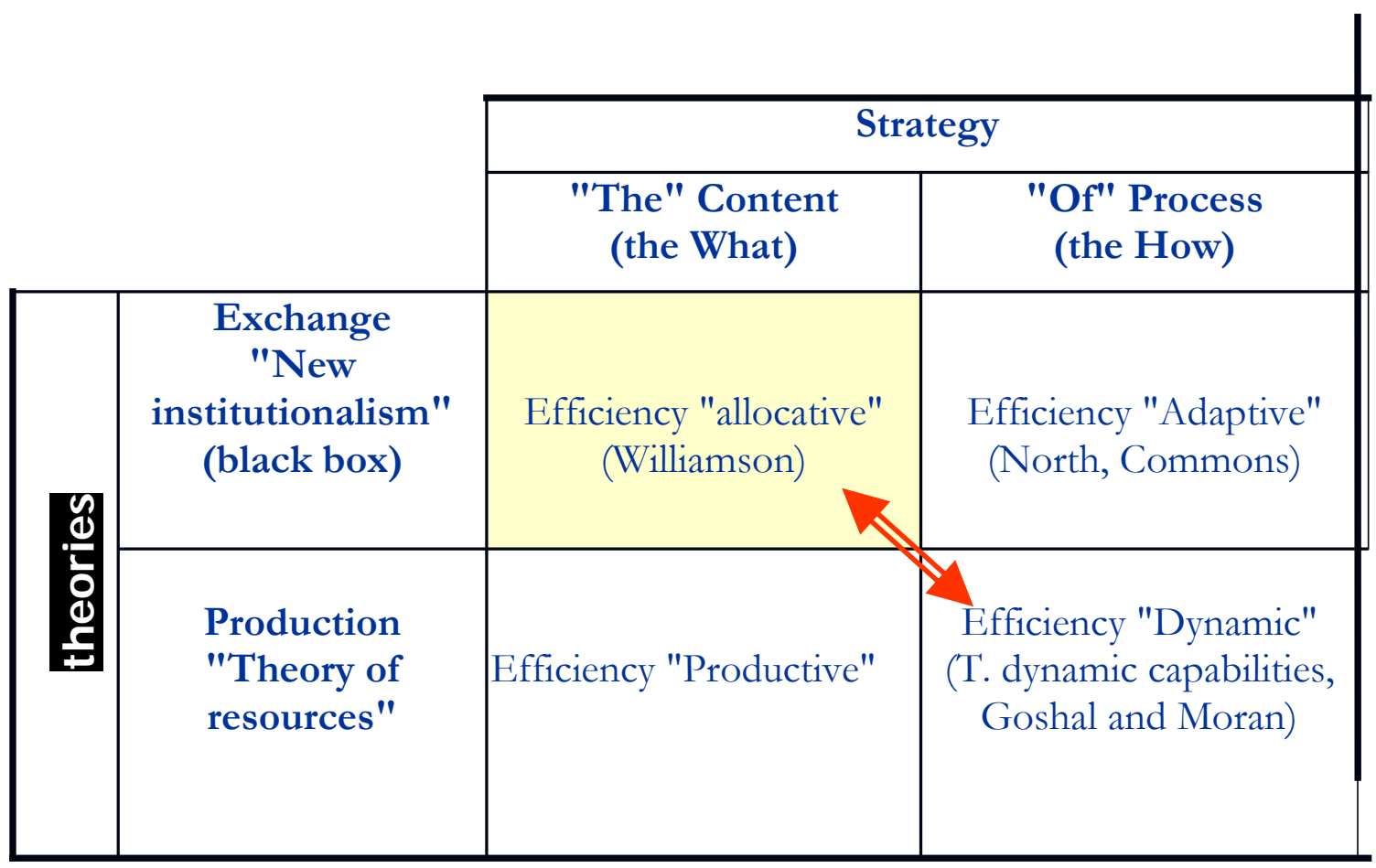

Fig. No. 1 - Analysis of time and control strategy level of interaction

Source: G. Solle, Evolution of management control, presentation by the Summer School, July 2011, Alba Iulia.

As we can see, the strategy has two directions: the purpose and the way forward. With other words the strategy answers the questions: Why? and how?. Modern management aims to achieve objectives that are part of the strategy of the entity. Therefore, arise the need of opportunities management decisions. Graphically, we can see the interdependence who takes birth between allocative efficiency and the dynamics.

Efficiency "Allocative" appears when price equals marginal costs and the property is made available to consumers at the lowest possible price. This is possible only when there is perfect competition. In fact discussing the efficient allocation of resources - Pareto allocation.

Efficiency "Adaptative" is the capacity of some company to adjust the flexibly to shock.

Efficiency "Productive" appears when firm produces the lowest point of the total average cost curve, meaning that the goods can not produce any cheaper.

Efficiency "Dynamic" refers to the ability to adapt quickly and at low cost to changing economic conditions and to preserve these economical outgoing and productivity performance.

We will focus more specifically to techniques and tools used in strategic decision support with emphasis on the use of the budget system and the importance of dashboards. The budget management should be considered as a decision assistance system and management control composed of two distinct phases: preparation of budgets (budgeting) budgetary control consists of the calculation of deviations and corrective actions. Budgeting is the determination of budgets. We will need the framework letter to the budget which will present the strategy of the organization.

Objectives therefore follow that strategy. Each responsibility center will be assigned targets and therefore budgets. The budget management will meet it's the roles that to the extent the network of budget covers all the activity of the company and respect the existing interaction between the subsystems that constitute it. However, budget management goes well beyond budgets and constitutes in itself a form of management that allows the involvement of managers and taking into account of the human dimension dynamics implications of any control mode. 
The dashboard is a tool with a set of relevant information and organized system to have an overview of the performance of business processes and make corrective actions in order to achieve objectives. The explorations have therefore oriented towards the components of the business strategy - the more readily that the concept refers to the branch or division in the charts, and that it is not the place of deployment excellence of management control.

\section{Conclusions}

The strategy is materializing on all kinds of reports or media presentations that the division president uses more or less solemn. These materials contain the main elements of the strategy but also rules that must apply to the actions of middle managers. Strategy and rules appear always accompanied by elements from the control systems. These elements serve both to justify the rules and to embody them in concrete examples of success for example. Control practices are organized around meetings (revised budget), conference calls and especially reporting. The strategy is always present, at least in the instructions that are given for completing the documents but often also to justify the inclusion or rejection of an argument made by the middle managers. Control and strategy are closely intertwined in practice.

The monitoring tools have evolved along with the strategy. This trend is not linear and is made of back steps. In some cases, monitoring tools are tailored to match the new policy decisions, but in other cases, the control system "locks" the manager of a specific framework to formulate its strategy.

Entities, regardless of size or profile must constantly prove its viability, adaptability and economic and financial performance. Information system management control captures and manages information for effective performance management as an entity.

The management and structuring of business entities need many changes. In the current economic environment, many phenomenons such as stagnation of economic activity, increased competition, inflation has contributed to increased vulnerability entities. Thus, management control should intervene in business entities and strategic decision making so that the entities to meet their objectives.

\section{References}

1. Albu N., Albu C., 2003. Performance management tools, Economica Publishing, Bucharest.

2. Albu C., 2005. An analysis of organizational learning through valuing managerial accounting tools, PhD thesis, ASE Bucharest;

3. Anthony R., Govindarajan, V., 2007. Management Control Systems, Chicago, Mc-GrawHill IRWIN.

4. Anthony R.N., 1988. The Management Control Function, Harvard Business School Press, Boston, MA.

5. Aslău T., 2001. Management control beyond appearances, Economica Publishing, Bucharest.

6. Atrill P., McLaney E., 2005. Management Accounting for Decision Makers, Editura Pearson Education, New York.

7. Ahrens T., Chapman C.S., Hopwood A.G., 2007. Handbook of Management Accounting Research, Oxford, Elsevier.

8. Ahrens T., Chapman C.S., 2007. Management accounting as practice. Accounting, Organizations and Society

9. Boisselier P., 1999. Contrôle de gestion, Editions Vuibert, Paris.

10. Bouquin H., 2004. Management accounting, translation and introductory study made by professor N.Tabără, Moldova Publishing, Iaşi. 
11. Bouquin H., 2004. Management accounting, Tipo moldova Publishing, Iaşi.

12. Bouquin H, 2006. Comptabilité de gestion, Paris, Economia, $3^{\mathrm{e}}$ éd.

13. Bouquin H., 2008. Controle de gestion, Presses Universitaires de France, Paris.

14. Briciu S., 2006. Managerial accounting. Theoretical and practical aspects, Economica Publishing, Bucharest.

15. Briciu S., 2008. Variable and fixed costs in company management: Annales Universitatis Apulensis Series Oeconomica, 10(1), $164-170$

16. Briciu S., Căpuşneanu S., Rof L., Topor D., 2010. Accounting and management control. Tools for measuring the performance on an entity, Aeternitas Publishing, Alba Iulia.

17. Briciu S., 2007. Responsibility centres' role in practicing a performing management, Annales Universitatis Apulensis Series Oeconomica, 9(1).

18. Capron M., 1994. Accounting in perspective, Humanitas Publishing, Bucharest.

19. Caraiani C., Dumitrana M., (coordonator), 2005. Management accounting \& Management control, InfoMega Publishing, Bucharest.

20. Căpuşneanu S., 2008. Elements of cost management, Economica Publishing, Bucureşti.

21. Chapman C., 2005. Controlling strategy. Management accounting and performance measurement, Oxford, Oxford University Press.

22. Chenhall R., 2003. Management control system design within its organizational context: Findings from contingency-based research and directions for the future, Accounting, Organizations and Society, 28(2-3), 127-168.

23. Colasse B., Lesage C., Tabără N., 2011. Introduction in accounting, Tipo Moldova Publishing, Iaşi.

24. Diaconu P., 2002. Managerial accounting, Economica Publishing, Bucharest.

25. Drury, C., 2006. Cost and Management Accounting,Thomson Learning.

26. Ebbeken K., Possler L., Ristea, M., 2000. Calculation and cost management, Teora Publishing House, Bucharest.

27. Fatacean G., 2009. Managerial accounting, Cluj-Napoca, Editura Risoprint.

28. Fabre P., Sépari S., Solle G., et al., 2009. DSCG 3-Management et contrôle de gestion, Editura Dunod.

29. Garrison R., Noreen E., Brewer P., 2009. Managerial Accounting, McGraw-Hill-Irwin.

30. Hamilton B., 2003. How to be a top strategic advisor. Strategic Finance (June)

31. Herath S.K., 2007. A framework for management control research, Journal of Management Development, Vol. 26 No. 9, pp. 895-915.

32. Horvath \& Partners, 2007. Controlling. Sisteme eficiente de creştere a performantei firmei, Editura C.H. Beck, Bucureşti.

33. Ionaşcu I., Filip A.T., Stere M., 2006. Control de gestiune, Ediția a II-a, Editura Economică, Bucureşti.

34. Lowe W.F., Puxty, T., 1989, Critical Perspectives in Management Control, Macmillan, Basingstoke, pp. 27-45.

35. Oprea Călin (coord.), 2002. Management accounting, Tribuna Economică Publishing, Bucharest.

36. Tabără N., 2009. Management control, Tipo Moldova Publishing, Iaşi.

37. Verboncu I., Zalman M., 2005. Management and performances, Universitara Publishing, Bucharest.

38. Weetman P., 2006. Management Accounting, Prentice Hall, Harlow.

39. http://www.jstor.org

40. www.springerlink.com

41. www.oxfordjurnals.org

42. http://search.ebscohost.com/ 